\author{
Agnieszka Karpowicz \\ Instytut Kultury Polskiej \\ Uniwersytet Warszawski \\ e-mail: a.karpowicz@uw.edu.pl
}

\title{
Algi księżnej Anny i bambusy Konrada Wallenroda. Mazurskie legendy „z odzysku”
}

Z materiałów turystyczno-promocyjnych rozsianych po miasteczku i sieci, zwiedzania ryńskiego zamku z przewodnikiem przebranym za Krzyżaka (a na co dzień nauczycielem historii w miejscowej szkole), z treści reklam dzisiejszego Hotelu Zamek Ryn i całego szlaku zamków krzyżackich, którego jest częścią, z prospektów, ulotek, materiałów promocyjnych i gazetek wydawanych okazjonalnie podczas Dni Rynu, a także spaceru po mieście z przewodniczką, wyłania się obraz spójnej tożsamości miejsca skoncentrowanej wokół kilku wątków. Spaja je wszystkie zamek stanowiący centrum tych opowieści. Jednocześnie narracyjnie powtarza się w ten sposób moment założycielski, ponieważ budowla faktycznie zapoczątkowała tworzenie się tej mazurskiej osady. Potwierdza to również centralne położenie topograficzne zabytku. Wznosząca się na wzgórzu największa, masywna bryła góruje nad otoczeniem, a miasteczko - głównie dzięki odbudowie krzyżackiego zamku - staje się dziś uroczą atrakcją turystyczną. Jest też ono rekonstruowane koncentrycznie, wokół zamkowego wzgórza, z zachowaniem spójności architektonicznej podporządkowanej specyfice zamku, której odpowiadają też dalsze prace rewitalizujące ryńskie zabytki. Zamek zajmuje centralne miejsce, jeśli chodzi o charakter wydarzeń i imprez organizujących wakacyjne życie Rynu: biesiady rycerskie, jarmarki, festiwale kultury średniowiecznej.

W każdej z tych opowieści - niezależnie od tego, czy istnieje ona w postaci ustnej, pisanej, cyfrowej czy jako widowisko - w różnych kontekstach 
powraca też jedna legenda związana, oczywiście, z zamkiem. Przyjrzyjmy się kilku jej wariantom:

\section{Księżna Anna w algach}

[...] w Spa Księżnej Anny warto oczyścić ciało np. w kąpieli na bazie soli morskiej i alg, zażyć relaksującego masażu bambusami lub zafundować zmęczonemu ciału niezwykle przyjemny masaż z kropelką miodu braci zakonnych.

Po każdym zabiegu w spa najlepiej przez godzinę odpocząć na leżaku nad basenem. Słuchając szumu wody, można wtedy zastanowić się nad losem białej damy. Według legendy wraz z nadejściem zmroku rozpoczyna ona swoją przechadzkę. Zamkowa legenda mówi, że to księżna Anna, żona księcia litewskiego Witolda, podobno zamurowana tu żywcem przez Krzyżaków. W latach 80. XX wieku archeolodzy próbowali wyjaśnić tę tajemnicę, znaleźli nawet trzy zamurowane nisze. Były puste ${ }^{1}$.

\section{Księżna Anna pod Grunwaldem}

a. W ścianach twierdzy podobno zamurowano księżną Annę. I choć dotąd żadnych szczątków nie znaleziono, to jedna z wciąż żywych legend, które od lat przekazują sobie z pokolenia na pokolenie mieszkańcy Rynu. Takich historii jest znacznie więcej. Przykład? Podobno Wielki Książę Litewski Witold właśnie na Zamku prowadził tajne rokowania z Krzyżakami przed bitwą pod Grunwaldem ${ }^{2}$.

b. I to z tym miejscem wiąże się historia nieszczęsnej księżnej Anny, żony księcia litewskiego Witolda, tego samego, który pomógł Jagielle pod Grunwaldem. A przecież obiecał Krzyżakom, że w decydującej fazie bitwy przejdzie na ich stronę. Złożył tę obietnicę właśnie tu, w Rynie, gdzie przyjechał z żoną Anną i dziećmi. Kiedy pojechał pod Grunwald, Krzyżacy zatrzymali w gościnie jego rodzinę. Pod Grunwaldem Witold do końca walczył po stronie Jagiełły. Podobno ze strachu przed buntem własnych rycerzy. Dość, że obietnicy danej Krzyżakom nie dotrzymał, a ci z zemsty, zamurowali żywcem księżną Annę i jej dzieci. W latach 80 . XX wieku prowadzono na ryńskim zamku prace badawcze. Archeolodzy znaleźli trzy zamurowane nisze, ale bez śladu kości... Historia księżnej Anny może być więc tylko legendą. W każdym razie zamek zyskał ducha ${ }^{3}$.

${ }^{1}$ K. Wolny, Z wizyta u Krzyżaków, http://www.voyage.pl/hotele/3322/z-wizyta-u-krzyza kow [dostęp 23.04.2014].

${ }^{2}$ M. Roik, Ryńska twierdza smaku, http://www.slowlifepolska.pl/nr/w_numerze/rynska_twie rdza_smaku.html [dostęp 23.04.2014].

${ }^{3}$ M. Grzywacz, Obiecanki cacanki czyli zamek Ryn, http://www.rmf.fm/swoja-droga/show,42, obiecanki-cacanki-czyli-zamek-ryn.html [dostęp 23.04.2014]. 


\section{Biała Anna z Rynu}

Ludzie stąd wciąż bowiem wspominają pewną legendę, związana z Zamkiem w Rynie. Według niej mieszkał tu i wciąż mieszka przynoszący szczęście dobry duch Białej Damy. Nie ma bowiem zamku bez Białej Damy! Ryńska Dama to Anna, żona litewskiego księcia Witolda. Sprzymierzony z Krzyżakami, chciał zdobyć koronę Litwy. To właśnie dlatego wciąż odwiedzał zamek w Rynie, by ustalić zasady sojuszu i, tuż przed samą bitwą pod Grunwaldem, zobowiązać się do przejścia na stronę Krzyżaków.

Aby udowodnić swoje czyste intencje, pozostawił na zamku żonę Annę oraz ich dzieci. Z historii wiemy, że Witold ostatecznie nie przeszedł na stronę Krzyżaków, lecz pozostał z Jagiełłą. Zemsta Krzyżaków była wielka - cała rodzina Witolda więziona była i ostatecznie zamurowana żywcem w zamkowych lochach. Ludzie powiadają, że właśnie od tego czasu, po zmroku lub nocą, po zamkowych komnatach przechadza się duch Anny, czyli Biała Dama z Rynu ${ }^{4}$.

\section{Biała Maria z Rynu?}

Legenda mówi, że kiedy Witold pogodził się z Jagiełłą i zdradził Krzyżaków, jego żona - księżna Anna wraz z dwójką maleńkich synów została zamurowana żywcem w sztolni młyńskiego kanału, biegnącego od jeziora Ołów pod zamkiem. Jej upiór w księżycowe noce nawiedza podobno korytarze i komnaty zamku, który obecnie pełni rolę hotelu. Legenda nie pokrywa się ze źródłami historycznymi, według których księżna Anna zmarła w 1418 r. i została pochowana w katedrze wileńskiej, ale mogło chodzić o pierwszą żonę Witolda księżnę Marię, o której losach średniowieczne kroniki milczą. Ale nawet gdyby legenda całkowicie rozmijała się z prawdą historyczną, ryński zamek mogą prześladować inne upiory. W połowie XIX stulecia ryńskie zamczysko przekształcono w więzienie, gdzie wykonywano wyroki śmierci. Istnieją przypuszczenia, że w latach drugiej wojny światowej dokonywano tutaj również eksterminacji ludności żydowskiej. Z zamku, w którym mieści się obecnie luksusowy hotel, roztacza się wspaniały widok na rozległą rynnę Jeziora Ryńskiego ${ }^{5}$.

\section{Księżycowa Anna}

Według legendy po Zamku w Rynie przechadza się przynoszący szczęście dobry duch Białej Damy. To podobno Anna - żona litewskiego księcia Witolda, którego celem - dzięki sprzymierzonym zeń Krzyżakom - było zdobycie korony Litwy. Z tego względu wielokrotnie odwiedzał zamek w Rynie, by ustalić zasady sojuszu i, przed samą bitwą Grunwaldzką, zobowiązać się do przejścia na stronę Krzyżaków, czego gwarancją mieli być zatrzymani na Zamku księżna Anna i jej dzieci. Jak pokazała historia, Witold nie zdradził Jagiełły, więc w ramach zemsty

${ }^{4}$ K. Enerlich, Biała Dama w Rynie, http://prowincjapelnamarzen.blog.pl/2013/07/03/bialadama-w-rynie/ [dostęp 23.04.2014].

${ }^{5}$ http://www.hotelmasovia.pl/pl/strona-glowna/atrakcje-turystyczne/16-trasa-zamkowkrzyzackich.html [dostęp 23.04.2014]. 
jego rodzinę zamurowano w zamkowych piwnicach. Od tego czasu, kiedy nad Zamkiem zapada zmrok, w księżycowej poświacie, po komnatach przechadza się duch białej damy. Wśród mieszkańców Rynu krążą również niesamowite opowieści o tajemniczych lochach, łączących zamek z kryptą nieistniejącego już kościoła i pobliskim cmentarzem. Przy odrobine szczęścia prawdziwość owych opowieści można sprawdzić osobiście ${ }^{6}$.

\section{„Od"-zyskiwanie ducha, „Od”-zyskiwanie ciała}

Podczas otwartego dla wszystkich chętnych spaceru organizowanego przez Ryńskie Centrum Kultury w sierpniu 2014 roku przewodniczka wspominała o spalonym kościele ewangelickim, młynie, ale i o podziemnym kanale zbudowanym przez Krzyżaków i łączącym dwa jeziora: Ołów i Ryńskie (część Tałt), między którymi położone jest miasteczko. Wśród atrakcji turystycznych i zabytków nie wymienia się raczej postawionego tu kiedyś, a dziś już nieistniejącego pomnika Fryderyka Wilhelma I, króla pruskiego, który nadał Rynowi prawa miejskie w 1723 roku, ani pomnika wystawionego po plebiscycie z 1920 roku, aby uczcić fakt, że za przynależnością do Polski nie oddano tu ani jednego głosu. Jednak w jakimś sensie wspomnienie o tych nieistniejących zabytkach odpowiadałoby logice spaceru będącego raczej penetrowaniem przestrzeni pozostałych po tym, co było. To dlatego przewodniczka najczęściej pokazuje grupie wpatrującej się w pusty plac stare, przedwojenne fotografie miejsca, o którym właśnie opowiada.

Zamek i pozostałości związanej z nim infrastruktury są niezmiennie w centrum opowieści, zwiedzających prowadzi się na wzgórze pod jego odnowione mury, jest to kulminacja spaceru, ale - co znamienne - to centrum obchodzi się dookoła, nie można go obejrzeć w ramach wycieczki organizowanej przez miejską instytucję, ponieważ jest on własnością spółki, do której należy zamkowy hotel. To $\mathrm{w}$ nim wygospodarowano niewielką powierzchnię dla zwiedzających, którzy zdecydują się wykupić bilet wstępu. Podkreśla to przestrzenne wyodrębnienie zamku, jakiś rodzaj jego obcości wobec reszty miasta, obcości paradoksalnej, ponieważ mówimy tu, po pierwsze, o rzeczywistym centrum miasteczka i miejscu założycielskim, a po drugie, o faktycznym osnuciu współczesnych, ryńskich działań promocyjnych i przemysłu turystycznego wokół zamkowych historii. Ta obcość podkreślana jest też czasem przez mieszkańców Rynu wspominających o tym, że bywają przepędzani przez ochroniarzy, gdy próbują przejść na skróty przez ogrodzony

\footnotetext{
${ }^{6}$ http://www.zamekryn.pl/zamek-ryn/historia/ [dostęp 23.04.2014].
} 
teren zamkowy (w praktyce nie udało mi się nigdy potwierdzić prawdziwości tych doniesień). Nie formułując zbyt prostych i banalnych wniosków, chciałabym zwrócić uwagę na kolejny paradoks.

Otóż jeśli zgodzimy się, że legenda to „domagająca się uznania swojej prawdziwości opowieść o wydarzeniu niesamowitym"7, dziwne wydać się mogą zachowania przewodników, którzy opowiadają o duchu księżnej Anny krążącym nocami po zamku: lekkie zażenowanie, wyraźne, niewerbalne wyznaczniki dystansu w stosunku do tego, o czym się mówi, ironia, mrugnięcie okiem. Uczestnicząc $w$ tych performance'ach ${ }^{8}$ nieustannie miałam wrażenie, że osoby opowiadające legendę jednocześnie dają wyraźnie do zrozumienia, iż same $\mathrm{w}$ nią nie wierzą, że nie jest to historia prawdziwa, że jest im niezręcznie ją przekazywać, a jednocześnie działali tak, jakby istniał jakiś niejasny przymus jej rozpowszechniania wbrew temu, co się prywatnie myśli. Ponadto wprowadzano ją formułami: „na pewno już słyszeliście”, ,jak pewnie już słyszeliście”, „na pewno już wiecie”, co sugeruje, że mówiący nie chciał nikogo tą niezwykłą historią zadziwić, lecz powtarzał ją z pełną świadomością, że jest opowiadana $\mathrm{w}$ Rynie niemal we wszystkich miejscach turystycznych, a jednak niezbędna, aby przewodnicki performance mógł się dopełnić (mimo znudzenia wyraźnie dającego się usłyszeć w głosie mówiącego i podkreślanego inicjalnymi formułami). Jednocześnie obserwowani przeze mnie przewodnicy nie angażowali się niewerbalnie w narrację, co mogłoby mieć wpływ na postawę odbiorców, być próbą zawarcia klasycznego paktu między nimi a opowiadaczem: „chodzi tu o gotowość do potraktowania opowieści zawierającej elementy na pierwszy rzut oka niewiarygodne, fantastyczne, cudowne lub szokujące jako prawdziwej (niezależnie od faktycznej wiary mówiącego czy słuchacza w jej prawdziwość)" $)^{\prime \prime}$.

Podczas performance'ów, w których uczestniczyłam, uwiarygodnienie legendy zastępowane było mimicznym i intonacyjnym podważaniem jej wiarygodności, co wydawać by się mogło sprzeczne z immanentnymi cechami legendy jako gatunku. Trudno jednak na tej podstawie stwierdzić, że opowieść o duchu księżnej Anny do niego nie należy. Na wszystkich innych poziomach przypomina ona dość klasyczną reprezentantkę podań „o czynach

7 O. Kaczmarek, Legenda, w: Od aforyzmu do zinu. Gatunki twórczości słownej, red. G. Godlewski, A. Karpowicz, M. Rakoczy, P. Rodak, Warszawa 2014, s. 241.

8 Używam tego terminu w znaczeniu nadanym mu przez Richarda Baumana, w odniesieniu do gatunków źródłowo oralnych lub opowiadanych ustnie, takich jak na przykład legendy, Sztuka słowa jako performance, przeł. G. Godlewski, w: Literatura ustna, wyb., wstęp, kalendarium i bibliografia P. Czapliński, Gdańsk 2010.

9 O. Kaczmarek, Legenda, s. 243. 
lub męczeńskiej śmierci”, które "stały się częścią regionalnych repertuarów opowieści, związanych z miejscami, wydarzeniami i problemami istotnymi dla lokalnej społeczności"10; jest podobnie jak legendy o rodowodzie hagiograficznym „wpleciona w turystyczną markę danego obszaru" ${ }^{11}$; opowiada o zdarzeniu niewiarygodnym, lecz na poły historycznym. W ryńskiej legendzie nie znajdziemy raczej śladów hagiografii, ale niewątpliwie pobrzmiewa tu ton martyrologii - czyż w świetle legendowej sugestii Witold nie poświęcił życia swojej żony i dzieci pozostając po „właściwej” stronie grunwaldzkiego pola bitwy?

Za pomocą mimiki przewodnicy podkreślali, że historia jest „bujdą”, „bajeczką dla naiwnych dzieci", dekonstruowali to, co było opowiadane, podważali prawdziwość przekazu w trakcie jego transmisji. Jednocześnie niezmiennie, zgodnie z klasyczną normą narracyjną, stosowali formuły uwiarygadniające treści tak charakterystyczne dla legendy, analogiczne do tych, które znajdziemy w materiałach internetowych i prasowych: „[...] wciąż żywych legend, które od lat przekazują sobie z pokolenia na pokolenie mieszkańcy Rynu” (2a); „Ludzie stąd wciąż bowiem wspominają” (3); „Wśród mieszkańców Rynu krążą również niesamowite opowieści" (5). Przewodnicy nie przekazują więc turystom legendy, lecz opowiadają, że miejscowi ją opowiadają, a, jak wiadomo, ta formuła służy właśnie podkreśleniu prawdziwości historii, która stanowi element wiedzy powszechnej społeczności, w jakiej funkcjonuje. Przewodnicy odwołują się więc do miejscowych autorytetów gwarantujących zakorzenienie legendy w lokalnej rzeczywistości społecznej. Temu służy też podawanie kolejnego dowodu, który natychmiast jest podważany - odkrytych przez archeologów, zamurowanych nisz. Fakt, że nie znaleziono w nich śladów kości, z jednej strony, przeczy autentyczności legendarnych zdarzeń, a z drugiej, natychmiast czyni je prawdopodobnymi. Jeśli bowiem nie znaleziono szczątków, to być może Anna istotnie przeniknęła przez grube mury i błąka się po zamku do dziś. Jeśli zaś prawda historyczna dotycząca Anny przeczy wiarygodności legendy, to wspomina się natychmiast o tajemniczej, innej żonie Witolda - Marii. Chodzi więc o stałe balansowanie na granicy wiary i niewiary $\mathrm{w}$ przedstawiane zdarzenia, o utrzymywanie napięcia między prawdą a zmyśleniem. Dodatkowo historyczne daty, fakty i realne odkrycia naukowe, podważające wiarygodność tej historii, pomagają podtrzymać jej prawdopodobność.

10 Tamże, s. 241. Zob. np. Podanie - legenda w tradycji ludowej i literackiej, red. M. Jakitowicz, W. Wróblewska, Torun 2007.

11 O. Kaczmarek, Legenda, s. 241. 
Przywołaną legendę można uznać za tradycyjną w treści i strukturze, a także pod względem charakteru postaci, której dotyczy - występuje ona powszechnie w polskiej demonologii ludowej ${ }^{12}$. Dziś jednak, w praktykach turystycznych, jest ona wyraźnie brana w nawias, w cudzysłów, opowiadający zaznacza własny dystans wobec opowiadanych zdarzeń. Oczywiście w wykonaniu doświadczonego i zaangażowanego w opowieść przewodnika-performera on również może służyć paradoksalnemu zasianiu niepewności na zasadzie: ,ja w to nie wierzę, ale...". Zauważmy też, że o ile legendzie przysługuje wariantywność, właściwa przekazom oralnym (a także tym, które zostały wtórnie spisane), opowieści cyfrowe, czytane przeze mnie i zasłyszane w Rynie, w zasadzie się od siebie nie różnią, co wzmacnia nieufność w stosunku do ich proweniencji. W zasadzie jedynym elementem, który pozostaje zmienny, jest podawanie różnych miejsc zamurowania Anny: (1) „zamurowana tu [w zamku - dop. A.K.] żywcem przez Krzyżaków”; (2a) „W ścianach twierdzy podobno zamurowano księżną Annę”; (3) „więziona była i ostatecznie zamurowana żywcem w zamkowych lochach"; (4) "zamurowana żywcem w sztolni młyńskiego kanału, biegnącego od jeziora Ołów pod zamkiem"; (5) ,jjego rodzinę zamurowano w zamkowych piwnicach". Różne miejsca zamurowania są ważnym zabiegiem konstrukcyjnym, podtrzymującym zasadność legendy, którą zawsze mogą podważyć kolejne odkrycia archeologiczne lub historyczne, dlatego też zapewne w niektórych opowieściach o miejscu dodaje się, że: „Mówi się wiele o tajemniczych lochach i nieistniejącym już tutejszym kościele oraz o połączeniu z pobliskim cmentarzem"13. Dzięki sugestii, że istnieje tu wiele innych tajemniczych i ukrytych obszarów, które mogą zamieszkiwać i inne duchy, miasteczko zyskuje jeszcze większy potencjał legendotwórczy.

W sposobach przedstawiania legendy "na żywo" przez lokalnych przewodników zauważyć można niepokojącą prześmiewczość wobec "cudzego słowa”, bo taki status ma przecież przytaczana opowieść miejscowych. Najciekawszy paradoks polega na tym, że - jak ustaliłam na podstawie wielu pobytów w Rynie i rozmów z jego mieszkańcami - w mieście dystans ten zaznaczają wszyscy wobec wszystkich: przewodnicy wobec słów „miejscowej ludności", a "miejscowa ludność" wobec przewodników "opowiadających bajki” naiwnym turystom, turyści zaś śmieją się ze zmyślenia "sprzedawanego" im zapewne zawsze, gdy zwiedzają jakikolwiek zamkowy gród. I nie jest to paradoks ostatni: choć utożsamiam się z „miejscową ludnością” ze względu na

12 Zob. W. Vargas, P. Zych, Duchy polskich miast i zamków, Warszawa 2013; L. J. Pełka, Polska demonologia ludowa, Warszawa 1987.

13 K. Enerlich, Biała Dama w Rynie. 
miejsce urodzenia, relacje rodzinne i wieloletnie, bliskie kontakty z Rynem, legendę tę poznałam dopiero kilka lat temu, właśnie dzięki współczesnym folderom, udziałowi w spacerach miejskich i zwiedzaniu zamku z przewodnikiem. Po raz pierwszy zaś usłyszałam o niej zdawkowo przy okazji odkryć archeologicznych w latach 80. XX wieku, trudno mi więc stwierdzić, czy przekaz krążył od wieków wśród mieszkańców Rynu. Osoby reprezentujące różne pokolenia rynian traktują legendę raczej jako opowieść wymyśloną na potrzeby komercyjne. Co ciekawe, zamkowe przestrzenie generują również typowe legendy miejskie: o demonicznych lub niepełnosprawnych umysłowo ochroniarzach i niewpuszczaniu "miejscowych" na teren zamku, o współczesnych gościach hotelowych - wyjątkowo wyuzdanych, rozpasanych, niewiarygodnie bogatych, a co za tym idzie, dopuszczających się w swoich pokojach niewiarygodnych czynów. Powinowactwo z legendami miejskimi ${ }^{14}$ jest tu wyraźne: historie te są formą oswajania obcości, czegoś nowego, co pojawia się $\mathrm{w}$ tkance miejskiej $\mathrm{w}$ momencie zmian, a odbierane bywa jako ingerencja w dotychczasowe życie mieszkańców zagrażająca status quo, pobrzmiewa $\mathrm{w}$ tym również lęk przed zawłaszczaniem przestrzeni publicznej. Właśnie raczej z tego typu historiami, niż z „oficjalną" legendą bardziej identyfikują się mieszkańcy miasteczka.

W przypadku ryńskiej Białej Damy najistotniejsza wydaje się rama komunikacyjna, w jakiej pojawia się legenda. Świadczy ona o tym, że współcześnie opowieść ta nie tyle jest legendą, ile jest jako taka przedstawiana. Mamy do czynienia z operacją dwustopniową: prezentowaniem tego, co się mówi, jako legendy, którą opowiada się wśród „ludu”, czyli konstruowaniem samego gatunku miejskiego, jakim tradycyjnie pozostaje legenda właśnie. Prawdopodobnie wymaga tego odwieczna zasada, według której każde stare, ważne historycznie miasto musi mieć swoją historię tego rodzaju. Informując o tradycyjnym rozpowszechnianiu tego, co się właśnie przedstawia (chociaż realnie nikt tradycyjnie tej historii nie przekazuje), konstruuje się więc jednocześnie samą tradycję i wspólnotę, wśród której krążyć ma legenda. Wytwarzanie gatunku ma istotną konsekwencję, jaką jest powołanie do życia pewnej społeczności.

Jest to gatunek twórczości słownej przekazywany ustnie i pierwotnie związany ze sferą folkloru. Istotnym odniesieniem dla legendy jest tradycja społeczności, w której jest rozpowszechniana. To ona bowiem określa w znacznej mierze treść i strukturę legendy, sposób jej przekazywania i odbioru a także dostarcza kontekstu jej interpretacji ${ }^{15}$.

14 Zob. D. Czubala, Wspótczesne legendy miejskie, Katowice 1993.

15 O. Kaczmarek, Legenda, s. 241. 
Jednak w przypadku Rynu sytuacja jest symetrycznie odwrotna: dzięki przekazywaniu legendy $\mathrm{w}$ narracjach turystycznych stwarza się $\mathrm{w}$ sferze symbolicznej jakąś - mniej lub bardziej wyimaginowaną - ludową tradycję i jej przedstawicieli. W ten sposób, gdy „zamek zyskał ducha” - również w znaczeniu najbardziej pierwotnym jako genius loci- mogło go zyskać miasteczko. Ta cecha ryńskiej legendy wydobywa specyficznie mazurską prawidłowość: kim mieliby być w tym wypadku „miejscowi” opowiadający legendę od pokoleń? I dlaczego faktycznie jej nie opowiadali w latach 70. XX wieku, a dziś wspominają o niej jako o narracji rozpowszechnianej jedynie przez zamkowy przemysł turystyczny?

Moja pamięć podpowiada, że w latach 80. i 70. przy rodzinnych uroczystościach legend i opowieści niesamowitych nie brakowało, tyle że dotyczyły one bardziej Baligrodu i okolic, czasem Wileńszczyzny, najbardziej niewiarygodne wydawały się wtedy wspomnienia najbardziej rzeczywiste, te z syberyjskiego „innego świata”. Potwierdzenie, że nie była to sytuacja wyjątkowa i osobna na tych terenach, nietrudno znaleźć we wspomnieniach innych przedstawicieli mojego pokolenia ${ }^{16}$.

Jeśli dziadkowie odgrywali najważniejszą rolę w przekazywaniu i podtrzymywaniu historycznych aspektów tożsamości miejsca, to pewnie nie było rzadkością, że przenosili tymi opowieściami na Mazury tożsamość inną, podkreślając, że są skądinąd. Poza tym sami te tereny wciąż poznawali, a historii doświadczali owszem, bardzo naocznie i namacalnie, ale w zupełnie innych miejscach. Być może krzyżacką legendę opowiadała garstka pozostałych tu jeszcze po wojnie rodowitych Mazurów: „,szwabów”, ,"krzyżaków”, ,"niemr” i „niemiaszków”, jak nazywała ich długo jeszcze miejscowo-nie-miejscowa, przyjezdna ludność. Sięgając znów do prywatnej pamięci miejsca, widzę niezbyt liczną grupę „obcych” (znów paradoksalnie, bo mówimy o rodowitych mieszkańcach Rynu w przeciwieństwie do tych, którzy zostali tu przesiedleni z innych regionów), „innych”, mówiących językiem kojarzącym się jednoznacznie z mundurem Wehrmachtu lub jakąś nieoczywistą odmianą tego języka, rozbrzmiewającą $\mathrm{w}$ letnie wieczory z kilku okien kamienic zamieniających się $\mathrm{w}$ nadziemne miejsca spotkań towarzyskich i międzysąsiedzkiego „szprechania” kobiet wygodnie opartych łokciami na wielkich poduchach rozłożonych na parapetach. Po ostatniej fali wyjazdów do RFN grupa ta kojarzyła się już dużo przyjemniej, choć równie obco, z zapachem przysyłanych przez sąsiadów paczek pełnych pomarańczy, anielskim smakiem czekolady „z okienkiem” i obezwładniającym aromatem mięciutkich ubrań

16 M. Olszewski, Zapiski na biletach, Warszawa 2010. 
"z odzysku”, który wydawał się wtedy bardziej efektem działania środka magicznego niż czegoś, co mogłoby mieć jakikolwiek związek z proszkiem Cypisek.

Nie sposób więc dowieść, że właśnie o tę „miejscową ludność” chodzi przewodnikom opowiadającym dziś legendę o Annie. Rodzinne opowieści przekazywały raczej doświadczenie zwielokrotnionej alienacji: „bycie u siebie" czyniło Mazurów obcymi w oczach grupy napływowej, która z kolei czuła się „nie u siebie" w miejscu aktualnego zamieszkania, co na mocy pamięci i rodzinnych wspomnień podtrzymywała $w$ historiach opowiadanych dzieciom i wnukom urodzonym już na Mazurach. Poczucie "bycia nie u siebie", a przynajmniej problematyczności miejsca zamieszkiwania, było chyba duchem Rynu, zanim rolę tę przypisano księżnej Annie. W tamtym okresie o nieoczywistość przynależności ludzi do miejsca i przynależności miejsca do ludzi można było wręcz potknąć się na każdym kroku: przy zaniedbanej kupie gruzu na zamkowym wzgórzu, o którego rachitycznym, turystycznym charakterze mogła świadczyć jedynie budka z lodami włoskimi, a latem zwłaszcza w sklepie lub piekarni, gdy Mazury najeżdżały rzesze turystów, "stonki" (jak ich powszechnie nazywano) wymuszającej na miejscowych jak najwcześniejsze ustawienie się w kolejce, żeby nie zabrakło towaru, "stonki” sprawiającej wrażenie tłumu, który przyjeżdża ,jjak do siebie”, i tak też się tu czuje. Specjalną kategorię turystów stanowiły wycieczki powolnie przemieszczających się, starszych ludzi wysiadających z nowoczesnych, niemieckich autokarów. Oni akurat faktycznie przyjeżdżali ,jak do siebie”, najczęściej $\mathrm{w}$ podróż sentymentalną do krainy dzieciństwa i młodości. W programie wychowawczym mieszkających wtedy na Mazurach dzieci niezbywalna była instrukcja, jak należy się wobec nich zachowywać, a żelazną jej zasadę stanowił zakaz brania od tych ludzi czegokolwiek: ani cukierków, ani szczególnie kuszących gum balonowych, nawet (!) „Donaldów” z kolekcjonerskimi komiksami, tak chętnie przez nich rozdawanych miejscowym maluchom. Równie dziwne były dziecięce odkrycia, że nie do końca wiadomo, czy mieszka się w Giżycku, w Lecu, Łuczanach, które jeszcze inni nazywają Lötzen; że Ryn ma też inną nazwę - Rhein. Już sam repertuar możliwych nazw jednej miejscowości przyprawiał o zawrót głowy.

To skumulowane poczucie obcości wydobywa z całą mocą fantasmagoryczność tradycyjnej wspólnoty, miejscowego folkloru i ludzi, którzy przekazywać by mieli sobie ryńskie legendy z pokolenia na pokolenie od czasów krzyżackich do dziś. Jest to wspólnota sztucznie preparowana podczas współczesnych aktów opowiadania legendy. Niewspółmierność zmyślenia i rzeczywistości w podaniu o księżnej Annie nie polega więc na tym, że „w rzeczywistości duchy nie istnieją", ani na tym, że Anna historyczna 
zmarła $\mathrm{w}$ innych okolicznościach niż ta legendarna, lecz na tym, że trudno wskazać wspólnotę miejscowych, wśród których tradycyjny przekaz miałby krążyć. W tym miejscu ta misterna konstrukcja rozpada się. Niewspółmierność tkwi więc w ramie pragmatycznej gatunku, jakim jest legenda, w nieprzystawalności kontekstu i niewiarygodności figury "opowiadającego ją ludu". Legenda pokazuje Ryn jako miejsce "takie jak każde inne", gładkie, z tożsamością, spójną historią, swoim genius loci, duchem Białej Damy takim samym, który krąży po niemal wszystkich polskich zamkach, pamięcią zbiorową sięgającą pradawnych źródeł. To właśnie samo „wmówienie” w Ryn istnienia legendy, będącej gatunkiem z pogranicza rzeczywistości, faktu i historii, dodaje miejscu autentyczności - to ona sama, a nie jej treść, „domaga się uznania" w akcie opowiadania.

To pęknięcie widać w jeszcze innej narracji ryńskiej, w której zamek jest równie ważnym elementem. W ryńskim muzeum zamiast legendy o księżnej Annie znajdziemy inne tajemnicze rekwizyty, jak magiczne lustro „o kryształowej tafli, które powie nam co nieco o naszym związku, gdy staniemy przed nim z ukochaną osobą. Wśród eksponatów jest również czarci zydel i zamurowana żywcem i przykuta łańcuchami, ostatnia mazurska czarownica"17. Widać więc, że ludowa demonologia organizuje narrację o miejscu. Jest ona szczególnie potrzebna $\mathrm{w}$ miasteczku, którego muzeum przypomina najwymyślniejszy Lévi-Straussowski bricolage sklecony naprędce $\mathrm{z}$ tego, co pod ręką: „Wśród ciekawych eksponatów znajdziemy dłubankę, łódź wydobytą z dna jeziora Ryńskiego. Jest to jedyny tego typu eksponat przedstawiony $\mathrm{w}$ warunkach muzealnych $\mathrm{w}$ województwie warmińsko-mazurskim. Ponadto zobaczymy przepiękny fotel gdański i XIX-wieczne plany zamku i kościoła ryńskiego, który został spalony w 1940 roku"18.

Budowaniu aury duchowego (także w sensie dosłownym, jak w legendzie o Annie) dziedzictwa ludowej tradycji unoszącej się nad Rynem służą również sprawy cielesne. Tę próbę wytworzenia efektu ciągłości i tradycyjności tego, co się dziś w Rynie oferuje, widać najwyraźniej w sferze kulinarnej:

Oferująca te wyszukane potrawy restauracja, to miejsce, w którym można skosztować smaków Warmii, Mazur i Podlasia. I to dosłownie, bo serwująca te oryginalne dania kuchnia bazuje nie tylko na produktach pochodzących z najbliższej okolicy, ale też często $\mathrm{z}$ wytwarzanych w tradycyjny sposób. Rosół jest $n p$. przyrządzany $z$ hodowanych na wolnym wybiegu kur zielononóżek, a mąka pochodzi z młyna, gdzie do jej produkcji - tak samo jak przed wiekami - używa

\footnotetext{
17 http://mazuryinfo.com/atrakcje/zabytki_i_historia/rynskie_zbiory_muzealne-468.html\# tab:offer_description [dostęp 23.04.2014].

18 Tamże.
} 
się kamiennych żaren. Wysublimowany rycerski smak to tylko jedna strona kulinarnego oblicza Rynu ${ }^{19}$.

Z materiałów promocyjnych dowiadujemy się znów, że: "Zamek Ryn to niepowtarzalny... smak", którego:

tradycja kształtowała się przez setki lat. I choć przez dziesięciolecia krzyżacka kuchnia zdawała się zapomniana, od kilku lat znów stała się wizytówką mazurskiej siedziby zakonnych komturów. A miejscowość słynęła z rozwiązłości kobiet, które właśnie tu częściej niż w innych krzyżackich miastach popadały w alkoholizm. Cóż w tym jednak dziwnego, skoro - jak wynika z historycznych zapisków - przed wiekami działało tam ponad 20 szynków! ${ }^{20}$

Mazurski Smętek, który posłużył dawniej jako przewodnik w podróży ku źródłom legendarnej polskości ziem pruskich ${ }^{21}$, dziś przybiera raczej postać rozochoconego Bachusa:

Wówczas zjeżdżają tam goście, by podczas tych bachanaliów oddać się wspólnemu biesiadowaniu. Rozrywka oraz tradycyjne ucztowanie od wieków królują w tych historycznych murach - podobno ryńscy komturowie lubili rozrywkę do tego stopnia, że z powodu hucznej biesiady nie wystawili swoich wojsk pod Grunwaldem! ${ }^{22}$.

Max Töppen, bliższy ludowych źródeł mazurskich oraz legend o bagiennych i jeziornych stworach, niż narracje pokrzyżackie, łączył predylekcję miejscowej ludności do alkoholu z mglistym, wilgotnym klimatem i przenikliwym zimnem ${ }^{23}$, aurą wyjątkowo sprzyjającą też melancholii. Tutaj jednak zakon krzyżacki zapewnia skojarzenie z ludyczną wizją średniowiecza, doskonale współgra znaczeniowo z przaśnością, targiem i jarmarcznością, ale i przestrzenią zabawy, obfitych uczt możnych panów.

Oczywiście jest to logika, wedle której tradycyjnie mazurskie może też być włoskie wino przechowywane w ryńskich piwnicach (około 120 gatunków) i radośnie witane w listopadzie na wzór święta francuskiego Beaujolais Nouveau. Jednocześnie we młynie zaaranżowanym dziś na restaurację,

\footnotetext{
19 M. Roik, Ryńska twierdza smaku.

20 Tamże.

21 M. Wańkowicz, Na tropach Smętka, Kraków 1988.

22 M. Roik, Ryńska twierdza smaku.

${ }^{23}$ M. Töppen, Wierzenia mazurskie z dodatkiem zawierajacym klechdy i baśnie Mazurów, przeł. E. Piltzówna, Warszawa 1894; tegoż, Historia Mazur. Przyczynek do dziejów krainy i dziejów kultury pruskiej, przeł. M. Szymańska-Jasińska, oprac. G. Jasiński, Olsztyn 1995.
} 
„można się poczuć jak w mazurskiej chacie sprzed wielu lat" ${ }^{24}$. Podobnie jak w przypadku legendy o zamurowaniu księżnej Anny, narracje te pękają w miejscu, gdzie mowa o ciągłości, spójności tradycji, której wehikułem jest ludność, miejscowi mieszkańcy. Nie chodzi mi nawet o to, że wiedza historyczna „wysublimowany rycerski smak” każe włożyć między bajki, gdzie jest też zapewne miejsce Białej Damy z Rynu. Wszelkie ,jak przed wiekami”, "tradycyjny sposób”, ,produkty regionalne” i te, „z których słynie region" 25, a zwłaszcza "smaki Warmii, Mazur i Podlasia”, mają potencjał autodekonstrukcyjny nie w momencie, gdy zapytamy: czy naprawdę tak robiono, gotowano, produkowano $\mathrm{w}$ przeszłości, lecz wtedy, gdy zastanowimy się nad tym: kto, kiedy i do kiedy, na jakim terytorium właściwie pielęgnował tę regionalną (mazurską!) tradycję sprzedawaną dziś w uroczym sklepiku Smaki Mazur, w którym oczywiście kupimy również dzieła rzemiosła ludowego. Podczas Dni Rynu na stoiskach z żywnością regionalną nie może zaś zabraknąć litewskiego chleba i kindziuka (jednocześnie relacje polsko-litewskie są raczej czymś przemilczanym w narracjach turystycznych, choć Krzyżacy wznieśli zamek głównie po to, by dać odpór pogańskiej Litwie). „Klimatyczny przeplataniec smaków regionu” ${ }^{26}$, o którym pisze się $\mathrm{w}$ materiałach promocyjnych, jest chyba najlepszym przykładem kolejnego wymiaru bricolage'u, "kleconego" tu na tej samej zasadzie, według której księżna Anna, żona Witolda, patronuje algom i masażowi bambusami, a sprzedawana w sklepiku "mąka pochodzi z młyna, gdzie do jej produkcji - tak samo jak przed wiekami - używa się kamiennych żaren". Ponieważ młyńskie koło kręci się nadal (choć już bezproduktywnie), stanowiąc atrakcję turystyczną przy budynku dawniej będącym młynem, a dziś zaadaptowanym na karczmę i sklep, spożywane i kupowane tam produkty mączne faktycznie mogą sprawiać wrażenie „tutejszych”, „miejscowych”.

\section{"Od"-zyskiwanie miasta, „od"-zyskiwanie pamięci}

Narracje ryńskie skoncentrowane wokół zamku przekonują niezmiennie, że pierwotnej obfitości, dzikości i średniowieczności - a wszystkie te wartości idą tu ze sobą w parze - można w Rynie doświadczyć naocznie i namacalnie, a nawet jej zasmakować. Jest to oczywiście historyczność uprzednio spreparowana:

\footnotetext{
24 M. Roik, Ryńska twierdza smaku.

25 Tamże.

26 Tamże.
} 
To jedyny mazurski hotel ulokowany w dawnym zamku krzyżackim. Co jest okazją nie tylko do tego, by spędzić kilka dni we wnętrzach, w których przed wiekami mieszkali zakonnicy, lecz także pozwala poznać historię w sposób najbardziej przystępny - na własne oczy ${ }^{27}$.

Uprzednie przygotowanie makiety nie zmienia jednak faktu, że: „Gdy gasną światła, a na rozstawionych stołach (może przy nich usiąść 500 osób) palą się świece, można mieć wrażenie, że wehikuł czasu przeniósł nas w epokę średniowiecza. Tak może poczuć się każdy, nie tylko dzieci" ${ }^{28}$.

Po pierwsze, uwagę zwraca to, że ryński wehikuł czasu naprawdę działa tak, jakby między XXI wiekiem a średniowieczem nic się nie wydarzyło, przez co chcę powiedzieć, że gest przywracania historii i pamięci miejsca (krzyżackość Rynu w drugiej połowie XX wieku nie była - delikatnie mówiąc - wydobywana na plan pierwszy) jest jednocześnie zabiegiem ich wymazywania. Po drugie, zamkowe narracje znów oferują specyficzny dla tego miejsca, etniczny bricolage:

pokazywane $\mathrm{w}$ gablotach oryginalne elementy uzbrojenia. Starosłowiańskie hełmy z X wieku, topór krzyżacki z wieku XV, czekany, włócznie, miecze - aż chciałoby się je wziąć w dłoń, zważyć, przymierzyć. Tym bardziej [sic] że świetności dawnych rycerskich czasów można doświadczyć, przebierając się w stroje dworskich dam, paziów i zakonnych rycerzy. Można je wypożyczyć w recepcji i chodzić po zamkowych korytarzach czy pójść na obiad ${ }^{29}$.

Ten ludyczny performance historii odbywa się bez historii w tym sensie, że nie ma ona podmiotu, lecz same rekwizyty i rekonstruowane budowle. "Takich spotkań z historią w zamku jest mnóstwo." 30 - głosi hasło promocyjne. Czyja jednak jest to historia? Czy starosłowiańska? I dlaczego nie pruska? Skąd symptomatyczne omijanie lub oszczędne używanie nazwy "Litwa” i jej pochodnych form gramatycznych, skoro "siłą pociągową" odzyskiwania ducha miejsca ma być legenda o żonie księcia Witolda? Wytwarzanie ciągłości i tradycji jest więc tworzeniem historii, która realnie nie ma żadnego pełnoprawnego podmiotu zbiorowego, bo trudno za niego uznać efekt tożsamościowego bricolage'u, będący zlepkiem dostępnych akurat elementów, zadziwiającym "przeplatańcem" rozmaitych wyobrażeń i zmiennych historycznie intencji tożsamościowotwórczych.

\footnotetext{
27 K. Wolny, Z wizytą u Krzyżaków.

28 Tamże.

29 Tamże.

30 Tamże.
} 
Równie ważna, jak genderowa przynależność bohaterki tej legendy, związana też w sposób oczywisty z niezaangażowaniem po którejś ze stron polityczno-bitewnych sporów, pozwalająca wyzyskać postać dla przyzamkowej „krainy łagodności”, czyli luksusowego spa, jest krzyżackość tej historii. Jeśli uznać, że tożsamość miejsca, w tym miasta, to „zbiór uwarunkowanych historycznie cech charakterystycznych dla miasta, które wyróżniają je spośród innych i wyrażają się wszelkimi działaniami, jakie są podejmowane w mieście w celu tworzenia jego swoistej osobowości i charakteru" ${ }^{31}$, to krótki, najstarszy i założycielski dla osady, krzyżacki wycinek jej dziejów - poświadczony jedynym, odbudowanym i odrestaurowanym, okazałym zabytkiem - stać się dziś musi w sposób naturalny podstawowym elementem formującym spójną tożsamość tego miejsca. Pomińmy jednak różne banalne odpowiedzi związane z przemysłem turystycznym, marketingiem i ekonomią. Co oczywiste, nie da się dziś budować marki miasta wokół blokowisk powstałych w czasach PRL tuż przy zamkowym wzgórzu ani wokół budki z lodami włoskimi w dwóch smakach. To, że odzyskiwanie legendy i związanej z nią krzyżackiej historii Rynu służy promocji, budowaniu jego marki, a w konsekwencji - sukcesowi komercyjnemu miasta i inwestorów, jest sprawą bezdyskusyjną. Bardziej interesująca wydaje mi się odpowiedź na pytania o to: dlaczego właśnie krzyżacka (a nie, dajmy na to, pruska) historia tak dobrze się dziś sprzedaje i jakim operacjom czy przekształceniom zostaje ona poddana, aby mogła działać skutecznie we wszystkich tych marketingowo-turystycznych wymiarach.

Zamek jako centralny, ale i dosyć stabilny - choć też wytworzony na nowo w trakcie odbudowy - element miasteczka organizuje więc współczesne narracje o Rynie. Jednak wieloletnie starania o reanimację kupki ruin i gruzów, jaką zamek był jeszcze niedawno, dowodzą nie tyle jego potencjału ekonomiczno-turystycznego jako takiego, ile zapotrzebowania turystów na ten, a nie inny rodzaj i kontekst historyczny narracji. Wszystkie te oczywistości denaturalizuje właśnie fakt, że jeszcze dwadzieścia lat temu nikt tego potencjału nie dostrzegał, podobnie jak $\mathrm{w}$ przypadku poniemieckich dworków zamienianych po wojnie na magazyny lub miejsca szkoleń dla traktorzystów, a następnie niszczejących i pozostawionych samym sobie czy raczej zarastającym wszystko mazurskim lasom. Nie wystarcza mi też deterministyczny dowód $\mathrm{w}$ sprawie $\mathrm{z}$ zakresu historii politycznej związanej z programowym działaniem władz PRL. W latach 70.-90. krzyżacki zamek ist-

31 E. Glińska, Socjologiczna i marketingowa koncepcja tożsamości miasta, w: Obywatelstwo i tożsamość w społeczeństwach zróżnicowanych kulturowo i na pograniczach, red. M. Bieńkowska-Ptasznik, K. Krzysztofek, A. Sadowski, t. 1, Białystok 2006, s. 34. 
niał, ale jego atrakcyjność w świadomości mieszkańców wydawała się raczej żadna, sypiąca się budowla groziła niebezpieczeństwem, z radością przyjęto by zapewne decyzję o jej zburzeniu, aby wreszcie „nie straszyła po nocach” i nie kazała się martwić, że wścibskie dzieciaki mimo zakazów zaczęły ją zbyt intensywnie eksplorować. Były to, jak sądzę, zupełnie niezideologizowane, zwyczajne reakcje codziennych użytkowników tej przestrzeni, niekoniecznie myślących wówczas o wrogiej „niemieckości” zabytku. Prowadząc badania dotyczące ryńskich legend uparcie poszukiwałam $w$ archiwach rodzinnych zdjęć - swoich dziadków, rodziców, własnych, a nawet przyjeżdżających do nas gości zwiedzających Mazury - na których w tle widoczny byłby choć fragment tej dzisiejszej atrakcji turystycznej. Poszukiwania spełzły na niczym, choć fotografowano te osoby w wielu ryńskich miejscach: nad jeziorami, w amfiteatrze, na pomostach, na tle żaglówek... Chodzi mi więc o zrozumienie specyfiki samego momentu, w którym krzyżacka część dziejów zaczęła być postrzegana jako centrum mazurskiej historii, ryńskiego dziedzictwa trwającego do dziś, i siła napędowa rozwoju regionu (losy ryńskiego zamku podzielił kilka lat temu między innymi mniej okazały zamek krzyżacki w Giżycku, dziś ekskluzywny Hotel St Bruno).

Ryński zamek to nie tylko mury, lecz także związane z nim legendarne postaci. Oprócz Anny i Witolda najważniejsza z nich to Konrad Wallenrod, rzekomo bohater poematu Adama Mickiewicza: „Bardzo możliwe, że pierwowzorem tej postaci był niejaki Fryderyk von Wallenrod, pierwszy komtur krzyżacki na zamku w Rynie [...]"32. Oczywiście to, że pierwowzorem w istocie nie był, w niczym nie przeszkadza, żeby to przypuszczenie nieustannie powtarzać jako ciekawostkę:

W 1393 r. ustanowiono tu komturię, której podlegały m.in. zamki w Kętrzynie, Giżycku i Ełku, a pierwszym ryńskim komturem został Fryderyk von Wallenrod, osadzony tu przez swojego brata Konrada - wielkiego mistrza zakonu. To właśnie Konrada Wallenroda uczynił Adam Mickiewicz tytułowym bohaterem swego romantycznego poematu. Jednak autentycznym pierwowzorem Mickiewiczowskiego Wallenroda był niewątpliwie Herkus Monte - pruski sierota przygarnięty, wychowany i pasowany na rycerza przez Krzyżaków. [...] Monte zdradził zakon i stanął na czele wielkiego powstania pruskiego przeciwko Krzyżakom. Próbował zjednoczyć plemiona pruskie, uczył je skutecznie walczyć z ciężkozbrojnymi rycerzami i odniósł wiele militarnych sukcesów. Powstanie załamało się, kiedy został pochwycony i stracony ${ }^{33}$.

32 M. Grzywacz, Obiecanki cacanki czyli zamek Ryn.

$33 \mathrm{http}$ //www.hotelmasovia.pl/pl/strona-glowna/atrakcje-turystyczne/16-trasa-zamkowkrzyzackich.html [dostęp 23.04.2014]. 
Wiedza o tym, że księżna Anna fizycznie nie mogła zostać zamurowana w zamku i podawanie tej informacji staje się obowiązkową częścią performance'u opowiadania legendy - analogicznie funkcjonuje opowieść o Konradzie Wallenrodzie. Chodzi tu, jak sądzę, o to, że postać ta bardzo mocno tkwi w polskiej świadomości zbiorowej, jest więc rozpoznawalna, a przy okazji splata pradawne dzieje miasteczka z historią Polski - choć znów chodzi tu o historię fantazmatyczną. Podobnie rzecz się ma w przypadku opowieści o żonie "księcia litewskiego Witolda, tego samego, który pomógł Jagielle pod Grunwaldem. A przecież obiecał Krzyżakom, że w decydującej fazie bitwy przejdzie na ich stronę. [...] Pod Grunwaldem Witold do końca walczył po stronie Jagiełły” (2b), który „ostatecznie nie przeszedł na stronę Krzyżaków, lecz pozostał z Jagiełłą” (3), doznał „zemsty Krzyżaków” (3) za to, że „pogodził się z Jagiełą" (5), i, ,jak pokazała historia" (5), polskiego króla nie zdradził. Tego potencjału na pewno nie ma prawdziwie ryńska pieśn Tomasza Molitora $O$ wtargnięciu tatarskim, zaczynająca się od słów „Ojczyzno tęskliwa, zalewaj się łzami, / Wspomnijcie, Prusacy! co się działo z wami" ${ }^{34}$.

Faktycznie Konrad Wallenrod jest w Rynie patronem nie tylko jednej z karczm (Karczma u Wallenroda), lecz także ogródków działkowych (Rodzinne Ogrody Działkowe im. Konrada Wallenroda w Rynie). Dekonstrukcją jego legendy zajął się z uporem Wojciech Wawrzyński, który w materiałach historycznych odnalazł tego bohatera jako postać mroczną, "człowieka dumnego, porywczego, skłonnego do okrucieństwa, wojowniczego i na koniec człowieka "szkaradnego oblicza»" 35. Jak dowodzi autor, dążył on do rozbicia unii polsko-litewskiej, a swojego brata, wielkiego mistrza Fryderyka Wallenroda uczynił komturem ryńskim. Demistyfikatorska motywacja Wawrzyńskiego to fundamentalna niezgoda na to, żeby „żyć w świecie fikcji jak ci, którzy wzięli sobie tego Krzyżaka za patrona" ${ }^{36}$. Problem polega jednak na tym, że "człowiek czarny, wielkiego oblicza, żądny zaszczytów, chciwy, niezbożny”, zwany „pospolicie, aby ubliżyć, Waltrödde, co po germańsku znaczy dziki piesek", który toczył wojny z Litwinami i Żmudzinami, a „wieśniakom pracującym w lasach kazał obcinać ręce i nogi" ${ }^{37}$, słabo sprawdzałby się $\mathrm{w}$ roli ducha opiekuńczego polskiego miasteczka. Demistyfikacja legendy o mickiewiczowskim rodowodzie jest jednak bezzasadna, ponieważ właśnie

34 Cyt. za: A. Wakar, Historia Rynu 1376-1945, w: Giżycko. Z dziejów miasta i okolic, red. I. Bernatowicz, Olsztyn 1983, s. 175.

35 W. Wawrzyński, Niemiecka pamięć o Krzyżakach i stosunek do pamiątek zakonnego budownictwa, w: J. Bieszk, Zamki Państwa Krzyżackiego w Polsce, Warszawa 2010, s. 9.

36 Tamże, s. 10.

37 Tamże, s. 10. Autor powołuje się głównie na dzieło księdza Jana Leo, Dzieje Prus (wydanie polskie Olsztyn 2008). 
na balansowaniu między prawdą historyczną a fikcją (tu: literacką) funkcjonuje legenda jako gatunek, wytrącając tym samym broń z ręki obrońców wszelkich "prawdziwych faktów".

W świetle tych rozpoznań księżna Anna jawi się jako duch wyjątkowo bezpieczny i medium przyjaznej historii, pozwalającej się odtwarzać w atmosferze radosnej zabawy: (3) „dobry duch Białej Damy” przynosi szczęście i opiekuje się zamkowym spa, w którym możemy pod jej patronatem sprawić sobie (1) „masaż bambusami lub zafundować zmęczonemu ciału niezwykle przyjemny masaż z kropelką miodu braci zakonnych". Być może jednak ta okrutna historia Wallenroda - mówiąca też wiele o losach miasteczka i tożsamości „miejscowego ludu” - pośrednio tłumaczy, dlaczego to właśnie słabo związana z miastem księżna i literacki Konrad Wallenrod tak świetnie sprawdzają się $\mathrm{w}$ roli opiekuńczych duchów miejsca. Nie chodzi tu jedynie o sprzężenie ich dziejów z losami Polski, lecz także o rodowód większości zjaw i duchów krążących po zamkach:

źródłem legend były nietypowe życiorysy, które wywarły na okolicznej ludności duże wrażenie. Dotyczy to głównie złoczyńców i okrutników, ale nierzadko też osób wyjątkowo dobrych. Po ich śmierci ludzie nie mogli się pozbyć silnych emocji z nimi związanych - czy był to paniczny lęk, czy nienawiść, czy wreszcie wielka miłość. Opowiadali więc sobie sąsiedzi dzieje owej postaci, podbarwiając ją za każdym razem, żeby lepiej wyrazić to, co do niej czują ${ }^{38}$.

Bohaterowie ci i łączące się z nimi znaczenia, zarówno w przypadku księżnej Anny, związanej z dziejami bitwy grunwaldzkiej, jak i Konrada Wallenroda, są bardzo czytelne, powszechnie znane wszystkim od dziecka, zajmują ważne miejsce w imaginarium polskiej kultury, dlatego też doskonale poddają się wszelkiego rodzaju mitotwórstwu. Turysta ucztujący w Karczmie u Wallenroda niekoniecznie musi dokładnie sprawdzić, o którego Wallenroda tu chodzi, a Witold, współtowarzysz i pomocnik Jagiełły, znany z wielkiego płótna autorstwa Jana Matejki, zapewnia analogiczną rozpoznawalność księżnej Annie. Przecież poza tymi wydarzeniami historia Polski i Rynu to dwie zupełnie inne opowieści, które pisane musiałyby być $\mathrm{z}$ dwóch różnych perspektyw, a może też z jakiejś jeszcze innej, alternatywnej, trzeciej. Nawet takie traumy polskiej historiografii, jak zabory: „W dziejach Mazur [...] niczem się nie zaznaczyły, pozatem że upadać zaczęły żywe przedtem stosunki handlowe z Warszawą" "39, co słusznie zauważył Mieczysław Orłowicz, doda-

38 W. Vargas, P. Zych, Duchy polskich miast i zamków, s. 5.

39 M. Orłowicz, Ilustrowany przewodnik po Mazurach Pruskich i Warmji, Lwów, Warszawa 1922, s. 25 . 
jąc od razu, że najdotkliwiej w historii regionu dały się z kolei odczuć wojny napoleońskie. W pewnym sensie legenda drugiego stopnia, jak ta o już legendarnym, mickiewiczowskim Wallenrodzie, pozwala tę dziwną, inną krainę oswoić, uchwycić miejsca, w których splot mazursko-polskiej historii nie jest nazbyt kłopotliwy i nie wymaga pokrętnych objaśnień, lecz pozwala beztrosko uczyć historii, bawiąc. Zaś odpowiedzi na pytanie, w jaki sposób większość polskojęzycznych Mazurów identyfikowała się z Niemcami, czemu dawała wyraz na przykład w głosowaniach plebiscytowych, nie oczekuje się zapewne podczas letnich rekreacji. A czyż Mazury nie są krainą wielkich i wiecznych, niczym niezmąconych wakacji? Odpowiedzi na pytania trudne pozostają więc domeną znakomitych opracowań naukowych, podobnie jak sam termin "wschodniopruskośćc 4 .

Podobne problemy miał już przed drugą wojną światową Mieczysław Orłowicz, gdy tworzył na zamówienie Ministerstwa Robót Publicznych w Warszawie swój przewodnik. Autor żadnych legend ryńskich nie przytacza, ale też trudno byłoby mu powołać się na "głos ludu", skoro sam przyznaje, że zwiedził Warmię i Mazury w 1913 roku i do czasu wydania książki w 1922 roku nie mógł zweryfikować zebranych informacji. Najpierw przeszkodził temu wybuch wojny, w 1920 roku przewodnik miał zostać opublikowany w celach propagandowych przez komitet plebiscytowy, ale po przegranej opcji propolskiej komitet rozwiązano. Gdy autor wydaje w końcu po dziewięciu latach swoją książkę (w ramach całego cyklu podobnych bedekerów po wszystkich ziemiach pruskich), nie ma do dyspozycji żadnych opracowań w języku polskim, w dodatku, jak przyznaje: „Układając przewodnik nie miałem możności ze względów politycznych przeglądnąć wszystkiego na miejscu" ${ }^{41}$. Szczerze przyznaje też, że niejedna informacja może dotyczyć czegoś, co już nie istnieje, a być może pojawiły się też elementy nieuwzględnione $\mathrm{w}$ przewodniku. Orłowicz widzi co prawda zalety terenu, gęstą sieć kolejową, stacje w niemal każdym mazurskim miasteczku: „Kto chce się stykać z Mazurami, powinien jeździć klasą IV, gdzie zresztą publiczność jest przyzwoitsza, niż w innych dzielnicach Polski w kl. III"42, omnibusy hotelowe, trolejbusy, liczne restauracje. Jednak wizyty w kawiarniach zdecydowanie odradza: „jak wszędzie w Niemczech fatalne, a kawa zła. Podają ogromne naczynie z czarną kawą, a maleńkie z mlekiem" ${ }^{43}$.

40 R. Traba, Wschodniopruskość. Tożsamość regionalna i narodowa w kulturze politycznej Niemiec, Poznań, Warszawa 2005.

41 M. Orłowicz, Ilustrowany przewodnik, s. 6.

42 Tamże, s. 38.

43 Tamże, s. 39. 
Według niego miejscowa ludność nosi polskie, ale przekręcone i zniekształcone nie do poznania nazwiska typu Wietschorek lub Gorrontzi, a także mówi szesnastowieczną polszczyzną ze względu na brak polskich wpływów od tamtej pory. Powiaty mazurskie są więc czysto ewangelickie: „Wśród ewangelickich Mazurów rozwija się silnie sekciarstwo (Święci, Gromadki, Sztundyści)" ${ }^{44}$. Jego zachwytu nie budzi tylko typ mazurskiej zabudowy. Ze względu na obowiązujący od 1886 roku zakaz krycia dachów słomą domy są murowane, okolone wysokimi, kamiennymi ogrodzeniami, dachy pokryte gontem i dachówką „pozbawioną piękna i swoistego charakteru" ${ }^{\prime 5}$. Z oczywistych względów ładniejsze są jego zdaniem katolickie chaty ludowe Warmii, drewniane i słowiańskie. Narracja przewodnikowa nieustannie prześlizguje się między próbą traktowania ziem pruskich jako źródłowo polskich, a dostrzeganą raz po raz ich kulturową innością, ocenianą negatywnie jako efekt niemieckiego zawłaszczenia terytorium. Już wtedy autor zauważał brak jakichkolwiek strojów ludowych, inny niż polski obrządek: sobótka, dożynki i „pasterka ewangelicka” ${ }^{46}$, jutrznia miałyby stanowić jedyne w zasadzie święta; dostrzegał, że ludzie zamieszkujący te tereny wyznają inną wiarę niż sąsiedzi-Polacy, a jednocześnie mówią innym językiem niż sąsiedzi-Niemcy. Ten „lud" nie mógł więc być wehikułem odwiecznie przekazywanych legend, które przetrwałyby bez zadraśnięć nawet ryńską tragedię "wyzwalania" tych ziem w 1945 roku.

Anna i Wallenrod są tak bezpiecznym elementem tożsamościowym, jak mazurska, dzika, obfita natura i jej dary. Wszystko dzieje się więc w odległych, baśniowych czasach, „Kiedy dzikie tereny Mazur porastały nieprzebrane lasy Puszczy Galindzkiej, a mazurskie jeziora zamieszkiwały wielkie ilości ryb, na przepięknym wzgórzu pomiędzy jeziorami Ryńskim i Ołów [...]" 47. Ryński wehikuł czasu przenosi nas więc w czasy świetności Rynu, gdy:

Puszcza Galindzka porastała wielkie przestrzenie, a jeziora obfitowały w ryby, których wystarczało dla każdego. Ludzie żywili się tym, co dał im las oraz tym, co złowili w srebrzystych falach. To właśnie wtedy na wzgórzu pomiędzy Jeziorem Ryńskim a Jeziorem Ołów ruszyła budowa pewnego zamku. Miał być średniowieczną warownią. [...] O zamku tym pisała kronika Wiganda z Marburga, pochodząca z 1377 roku. Z niej właśnie dowiadujemy się, że owa warownia dała początek miastu, które przed wojną nazywało się Rhein, a dziś

\footnotetext{
44 Tamże, s. 13.

45 Tamże, s. 13.

46 Tamże, s. 14.

47 http://www.zamekryn.pl/zamek-ryn/historia/ [dostęp 23.04.2014].
} 
to Ryn. [...] Dziś brzmi to zdumiewająco, ale w tamtych czasach Ryn miał połączenie z Bałtykiem! ${ }^{48}$

Czasy krzyżackie są więc ostoją obfitości, dostatku, nowoczesności i europejskości Rynu. Jednocześnie walory te uzgadnia się w narracjach $\mathrm{z}$ wizerunkiem Mazur jako wielkiej enklawy natury, żywienia się jej darami, ekologii, zieleni i życia blisko przyrody, bezkresnych terenów zielonych istniejących tylko po to, żeby je kontemplować i wypoczywać. Co znamienne, i dziś, w XXI wieku, można by powtórzyć za autorem przewodnika po tych terenach z 1922 roku, że chociaż Ryn uzyskał prawa miejskie w XVIII wieku, to zachował na pół rolniczy charakter. W kontekście wizerunku Mazur w świadomości zbiorowej, a także ogromnej - i dobrze już opisanej - roli dzikiej, nieskażonej przyrody w narracjach turystycznych i przewodnikowych, tropiąc legendę odnaleźliśmy Barthes'owski mit: „W micie historia wyparowuje; jest to rodzaj idealnej służby domowej: przygotowuje, przynosi, rozkłada, przychodzi pan, a służba po cichu znika - pozostaje tylko cieszyć się, nie zastanawiając się nawet skąd pochodzi ten piękny przedmiot. Albo lepiej: skąd mógłby pochodzić, jak nie z wieczności" ${ }^{49}$. Najbardziej wieczna i niewinna jest zaś natura, wspomagająca też „cudne wyparowanie historii" ${ }^{50}$. Jaka jest więc w tej narracji rola na wskroś historycznych Krzyżaków?

$\mathrm{Na}$ pewno trudno by było uczynić elementem tożsamościowym inny okres dziejów Rynu lub nawet ten sam, ale widziany z nie-grunwaldzkiej perspektywy: „Podczas wojny polsko-krzyżackiej (pruskiej), w 1520 roku, wojska mazowieckie pustoszyły wsie w okolicach Rynu, nie oszczędzając nawet kobiet i dzieci. W 1. połowie XIX wieku zamek stał pusty i niszczał nie znajdując nabywcy" ${ }^{51}$. Spalenie zamku w 1656 roku przez Tatarów, powstanie pruskie, przyznanie praw miejskich wymarłej osadzie, wyludnionej po przemarszach wojsk i epidemii zarazy, po to, by ją na nowo zaludnić oferując znaczne przywileje osiedleńcom, pożar z 1881 roku i przebudowa w stylu neogotyckim, uczynienie $\mathrm{z}$ niego po odbudowie magazynu wojskowego, a następnie więzienia, dwudziestowieczne zaaranżowanie pomieszczeń na magazyny, obsługę administracyjną miasta i okolicznych Państwowych Gospodarstw Rolnych - to wszystko rzeczywiście działo się między czasami krzyżackimi a współczesnością. Jednocześnie wydarzenia te obfitują w zmory, zjawy i duchy. W zamkowym więzieniu wykonywano wyroki

\footnotetext{
48 K. Enerlich, Biała Dama w Rynie.

49 R. Barthes, Mitologie, przeł. A. Dziadek, Warszawa 2000, s. 287.

50 Tamże.

51 J. Bieszk, Zamki Państwa Krzyżackiego.
} 
śmierci, w czasie drugiej wojny światowej prawdopodobnie tu dokonano eksterminacji tutejszych Żydów. Mówi się o tym co prawda w jednym z materiałów prasowych (4), ale wywód poprzedza typowe dla legendy wprowadzenie, odpowiednik "podobno” („istnieją przypuszczenia”). Narracja natychmiast też płynnie przechodzi do "luksusowego hotelu" i roztaczającego się ze wzgórza "wspaniałego widoku na rozległą rynnę Jeziora Ryńskiego" - dzieła odwiecznej i łagodzącej wszystko natury. Wydarzenia historyczne są jednocześnie przesunięte $\mathrm{w}$ sferę fikcji, zyskują status równy legendzie o księżnej Annie.

Legendy ryńskie nie tyle uwiarygodniają to, co niewiarygodne, za sprawą historycznych dat, wydarzeń i odniesień, ile służą zniesieniu historii i historyczności miejsca, przesuwając je performatywnie w sferę fikcji, zmyślenia, zabawy. $Z$ wielu powodów, jak się wydaje, dobrze jest, gdy upiorem, który nocami krąży po zamczysku, okazuje się "dobry duch Białej Damy”, duch zastępczy, zwykle spotykany we wszystkich zamkach, oswojony, taki, którego nikt się nie boi, ale którego każdy może z dystansem obśmiać i pobłażliwie "między bajki włożyć", zapadając w spokojny sen. Gdyby którejś księżycowej nocy gdzieś z zamkowych lochów faktycznie dobiegły niepokojące szurania, jęki czy stukoty, a po dziedzińcu przemykały cienie zjaw, będzie wiadomo, że nie ma się czego bać, bo żaden inny duch poza dobrotliwą księżną nie może tu dopominać się o pamięć.

\section{The Algae of Duchess Anna and the Bamboos of Konrad Wallenrod - Masurian "Recycled" Legends \\ Summary}

The text concentrates on the multidimensional aspects of transforming a Masurian town into a tourist attraction. The analyzed material includes tourist brochures, museum guides and leaflets, town promotion events, fairs, and festivals. The article demonstrates what role folk literature and local lore play in the recapturing of the site identity, especially when it is part of Recovered Territories. It further shows how certain aspects of this process are forgotten. The author investigates cultural meanings of such procedures, uncovers attitudes towards history and local memory, and finally asks questions about their role in contemporary culture.

Keywords: Masurian legends, site identity, local memory, Recovered Territories 